\title{
Prostate Adenoma
}

National Cancer Institute

\section{Source}

National Cancer Institute. Prostate Adenoma. NCI Thesaurus. Code C4795.

Focal benign glandular hyperplasia in the prostate gland. 